\title{
REVENGE IN JEFF NATHANSON'S MOVIE SCRIPT THE LION KING
}

\author{
Cici Alfi Syahrin, M. Amrin Siregar \\ Faculty of Literature, Universitas Islam Sumatera Utara \\ e-mail: syahrincici@gmail.com
}

Received: 2021-11-02

Accepted: 2021-11-21

\begin{abstract}
This study discusses the revenge carried out by the protagonist in The Lion King movie script named Simba. This study aims to analyze the revenge and purpose of revenge carried out by Simba. The method used to analyze this topic is a qualitative research method, making a focus on personality of the protagonist pertaining to revenge. A revenge is an act of justice as well as injustice, depending on how a revenge is done. This research is conducted by referring to and based on several literature reviews related to the topic and discussion carried out. The theory used to analyze the topic is put forward by Leland R. The results showed that Simba tried to take revenge because he felt he had been attacked. Besides, he wanted to restore his dignity, honour, and teach a lesson to his aggressor. Finally Simba gets what he deserves, that is he gets his rights as king in the Pride Lands.
\end{abstract}

Keywords: revenge, Simba, Scar, movie script.

\section{Introduction}

Literature is a beautiful written work that records something in the form of language that is condensed, deepened, twisted, shortened and twisted, made odd or other aesthetic composition methods through language tools (Eagleton, 2010: 4).

Esten (1978: 9) argues that literature is the expression of artistic and imaginative facts as a manifestation of human life and society in general through language as a medium and has a positive effect on human life.

One of the types of literature is drama. Drama is a literary work written in the form of dialogue with the intention of being shown. It can be performed in various forms, such as theatre performances, plays, films, soap opera, and so on. All forms of drama are created from dialogues that are played to identify events, actors and characters by the players with the support of an appropriate setting. Drama can amaze the audience if the player succeeds in playing the drama character with the appropriate character.

Elements in drama are not much different from elements in short stories, novels, and romances. Dialogue is a formal feature of drama that distinguishes it from other forms of prose. In addition to dialogue, there is a plot/characters, and setting. If the drama as a script is staged, it must be equipped with elements: motion, fashion, makeup, stage setting, sound system, and lighting.

Film or movie which is basically in the form of drama can be interpreted in two senses. First, the film or movie is made of celluloid for negative image holder (which will be made a portrait) or for a positive image holder (which will be played in the 
cinema). Second, film or movie is defined as a play (story) of a living picture. As an industry, film or movie is something that is part of the economic production of a society and it is considered as another product. As communication, films or movies are important parts of the system used by individuals and groups to send and receive messages (Ibrahim, 2011: 190).

Through this research, the researchers discuss one of the literary works, namely a drama. The drama has already been performed in the film or movie entitled The Lion King written by Jeff Nathanson. The Lion King is an animated film or movie produced by Walt Disney Feature Animation which was released to theaters by Walt Disney Pictures on June 15, 1994, and released to the public on June 24, 1994. This film or movie is the 32nd film in the series of Walt Disney classic animated films. This is a digitally enhanced high-definition version made in IMAX format for release on December 25, 2002. This constitutes a musical drama genre film featuring songs by Elton John and Tim Rice and music by Hans Zimmer.

The Lion King tells the story of Simba (Swahili for lion), a young lion who is to succeed his father, Mufasa, as King of the Pride Lands; however, after Simba's paternal uncle Scar murders Mufasa. Simba is manipulated into thinking he was responsible and flees into exile. After growing up in the company of the carefree outcasts Timon and Pumba, Simba receives valuable perspective from his childhood friend, Nala, and his shaman, Rafiki, before returning to challenge Scar to end his tyranny and take his place in the Circle of Life as the rightful king.

The benefits of this research are in the form of theoretical and practical benefits. Theoretically, the researchers and the readers can enrich their knowledge in analyzing the scripts of the movies. Practically, it is hoped that this research can develop insight in analyzing literary works, and for audience, this is expected to increase the ability to understand and appreciate literary works and to help the audience express the meaning contained in the movie script. The researchers see that this film contains good moral lessons because it can guide us not to do things that make other people take revenge on us. Revenge, of course, is not good and can be dangerous for both the vengeance and the other person who is being retaliated against. Hopefully this research can be useful for readers in general and especially for researchers who are interested in topics related to revenge.

\section{Literature Review}

Revenge is a behavior that is rampant and often appears in the form of aggression or conflict. The desire for revenge can be a person's motivation to kill, hurt others and even the occurrence of international conflicts (McCullough, 2008).

It can be defined that revenge is an act of retaliating for the action of others by hope to get a better feeling, more valuable and restore a sense of justice to one's self but feel better it is only temporary and sometimes poses new dangers to people who seek revenge (Baron. et. al., 2005).

The desire for revenge is not content to see the guilty suffer, but more satisfied if the moral message is conveyed. Someone takes revenge to convey a message to the person who is the target of revenge and make him understand that what he did was an act which violates morals. Revenge is defined as a reactionary behavior to feelings injustice meant to rebuild a sense of justice by getting or even giving to people who do what guilt he should receive. The act of revenge brings one to the contemplation of one 
who did wrong, prolonged contemplation produces negative feelings, negative feelings prolonged contemplation produces contemplation and the contemplative person will fail to predict the effect of punishment on those contemplations and feelings (Ross, et. al, 2010). Research has found that people who take revenge by punishing do not feel better. The perpetrator of revenge will continue to think about the person who was retaliated against (Crombag, 2003).

According to Sinclair, et al. in Collins Cobuild English Language Dictionary (1987: 1242), revenge is something that you do to hurt or to punish someone who has hurt or harmed you, that gives you a great deal of satisfaction. If you revenge yourself for a harm or wrong that has been done to you, you hurt or punish the person who has done the wrong or harm.

Some theorists add an additional element to their definition of revenge, arguing that a behavior can be classified unequivocally as revenge only if it involves some cost or risk to the avenger (Cota-McKinley A. L. et al., 2001, and Crombag. et al., 2003).

An important psychological implication of the various efforts to define revenge is that there is no objective standard for declaring an act to be motivated by revenge or not.

Revenge is a label that is ascribed based on perceivers' attributions for the act. Revenge is an inference, regardless of whether the individuals making the inference are the harm doer themselves, the injured parties, or outsiders. Because revenge is an inference, various individuals can disagree on whether the same action is revenge or not.

Cota-McKinley A. L. et al., (2001) state in their article, in the act of revenge, individuals respond to a wrong by harming the transgressor. Revenge can also refer to the urge to pay back wrongs; thus, a person can have revenge in his life. Revenge is an inference, regardless of whether the individuals making the inference are the harm-doers themselves, the injured parties or outsiders.

Many theorists assert that revenge offers personal and societal advantages. According to evolutionary psychologists, revenge serves three adaptive functions (McCullough, 2008). First, the mere possibility of revenge deters potential transgressors. Individuals with reputations for being vengeful are less likely to be victimized because the potential costs are high. Second, if a transgression does occur, revenge deters further harm by penalizing wrongdoing. Finally, revenge fosters cooperation by preventing individuals from taking advantage of the work carried out by others.

People's use of revenge to restore justice is also hypothesized to be psychologically beneficial. The researchers found some descriptions of revenge by experts in the same article by Ross and Schumann (2010) those are according to Equity theory (and like formulations), individuals experience distress when they have been treated unfairly. Revenge may enable victims to reduce their distress by restoring equity with the transgressor (McCullough, 2008). Similarly, Minderop (2011: 274) observed that one of the most infuriating aspects of being unjustly harmed is the awareness that he walks in pleasure and I in suffering. Revenge does not undo the harm, but it can restore the balance of suffering between the victim and the transgressor. Revenge can also help restore the balance of power between the victim and the transgressor. By inflicting harm, transgressors imply that their victims are unworthy of respect. Through vengeance, victims can restore their self-worth by showing they are not powerless. 
Ross and Schumann (2010) state in their article, it comes as no great surprise that very angry individuals often feel an urge to take revenge against people they blame for an injustice. More interesting, perhaps, are factors that influence whether angry victims choose to take revenge. There are four predictors of revenge behavior: the persistence of anger, perceptions of the costs of revenge, cultural and religious values regarding revenge, and the presence of external systems that can restore justice on behalf of victims. Transgressions and acts of revenge occur within a social context that includes at minimum two individuals, a transgressor and a victim. The actions of the transgressor can influence the likelihood and severity of revenge, by affecting both the degree of anger and the perceived costs of revenge. If victims become convinced that the transgressions were unintentional, or that their transgressors truly respect and care for them, or that their transgressors are otherwise good people, their anger dissipates and they are less inclined to seek revenge.

According to some opinions of the experts above, it can be concluded that revenge is an action that exists in human mind, the desire to take revenge is owned by every individual who feels he has received injustice, betrayal, and other negative treatments. Revenge is also an emotion that is present in human mind causing tensions and conflicts. Tensions and conflicts are part of the human personality, because they are unconsciously in human mind which determines how the structure of thinking, feeling and behaving of the humans being themselves (Sigmund Freud in Albertine Minderop ${ }^{\text {ee }}$ book, 2011).

There must be the reasons why people seek revenge and what they are looking for. We need also know what they actually hope to accomplish and why the passion is so strong. People seek revenge when:

1. They feel they have been attacked and suffered some unjust loss or injury. As a result they are feeling anger, hatred, jealousy, envy, or shame.

2. They are humiliated, especially if they are made to feel powerless, foolish, ridiculous, stupid, or ashamed. People seek revenge against the more powerful while they pity the less powerful.

3. They feel they have to "defend the honor" of themselves, their family, ancestors, or some other group they identify with.

The goals of revenge are to erase shame, humiliation and restore pride. In other words, the goals are to:

1. Restore their dignity, and increase their pride or stature.

2. Restore the "honor" of the offended group by avenging the shame.

3. Remember a loved one or ancestor. The slogan "September 11, 2001, we will never forget" is seen frequently and is used to sustain the war on terrorism. War memorials serve a similar purpose. In contrast, consider how the Amish people of Nickels Mines Pennsylvania reacted after five of their children were senselessly murdered. They razed the schoolhouse where the tragedy occurred to remove the most prominent symbol of the tragedy and leave a quiet pasture in its place. Their goal is to forgive and move on.

4. Teach a lesson to the aggressor,

5. Punish people who cheat and break rules; ensure they learn their lesson.

6. Act as a deterrent to predatory behavior,

7. Obtain acknowledgement from the aggressor that they were wrong and they feel remorse,

8. Obtain a sincere apology and know the aggressor is remorseful, 
9. Demonstrate their power so they no longer feel powerless,

10. Obtain reparations; get paid back for their losses, and settle the score

11. Make the aggressor suffer and feel their pain,

12. Transform themselves from prey to predator, from powerless to powerful, and from shamed to proud,

13. Tell their side of the story; set the record straight from their point of view.

\section{Research Method}

Research methods are the strategies, processes or techniques utilized in the collection of data or evidence for analysis in order to uncover new information or create better understanding of a topic. They represent the procedures so that the techniques are used to identify, collect, select, process and analyze information. Therefore, in this chapter, the researchers present research design, data collection, and data analysis.

Research design can be interpreted as a plan structured work in terms of the relationships between variables comprehensive in such a way that the research results can provide answers on research questions. The plan includes the things to be conducted research, starting from making hypotheses and their implications operational until the final analysis.

Ary et. al. (1985: 21) states that research may be defined as the application of the scientific approach to the study of a problem. Problem is something which has to be solved. Thus, research is required to look for the answer relate with problem which want to be solved. In research, the researcher must have design to make easy in analyzing the data. A research design is a plan or strategy for conducting the research. It is required to get dependable and useful information. To know what design which should be taken by the researcher, the first the researcher has to look at the problem of research.

\section{Discussion}

In this research, the researchers make an analysis to know why the protagonist of the movie seeks revenge and what is the protagonist's goal that makes the protagonist has the revenge.

\subsection{Reasons for Seeking of Revenge \\ 4.1.1 Feeling Attacked}

The protagonist revenge in the movie script is seen since Scar, Mufasa's younger brother, is jealous of Simba's position as heir to the throne, and he teams up with the hyenas to try to get rid of him. Scar traps Simba in a wildebeest chase. Although Simba is helped by his father, Mufasa himself dies when Scar falls from a cliff into the beast's pursuit. Simba escapes when Scar orders the hyenas to kill him.

The first reason for seeking revenge in the movie script comes from an attack by Scar, Simba's uncle with his army. Scar always tries hard to get rid of Simba from the Pride Lands. But the victim is Mufasa as it can be seen in the following quotation:

"All animals run through the scene as a stampede.

Simba: \{Quietly\} Dad? Somebody? Anybody? Help!

Scar: Simba. ... What have you done?

Simba: \{Jumps back, crying\} There was a stampede and he tried to save me... it was an accident, I... I didn't mean for it to happen... \{Sniffing $\}$ What am I gonna do? 
Scar: Run away, Simba.... Run.... Run away, and never return." (Nathanson, 2019: Scene, 29)

The above quotation shows that Scar orders his troops to kill Simba to become the successor to the throne of the kingdom, but the victim is Simba's father when he saves Simba from the attack.

\subsubsection{Humiliated, because of being made to feel powerless, foolish, ridiculous, stupid, or ashamed.}

The protagonist also feels revenge because Scar accuses Simba that he is the cause of his father's death and orders Simba to leave Pride Lands and never return. It is seen in the following quotation:

Scar: Simba. ... What have you done?

Simba: \{Jumps back, crying\} There wasa stampede and he tried to save me... it was an accident, I... I didn't mean for it to happen... \{Sniffing\} What am I gonna do?

Scar: Run away, Simba.... Run.... Run away,and never return. (Nathanson, 2019: Scene, 29)

The quotation explains that Scar has ordered Simba to never return so that he would replace Mufasa's role and Simba's role as king in Pride Lands.

The other reason for seeking revenge of the protagonist is caused by Scar. Scar tells the lioness that Mufasa is already dead and that his death is a terrible tragedy as well as the loss of Simba from Pride Lands. It is seen in the following quotation:

"Scar: Mufasa's death was a terrible tragedy; but to lose Simba as well.

Scar: ...For me, it is a deep personal loss. And so it is with a heavy heart that I assume the throne. Yet, out of the ashes of this tragedy, we shall rise to greet the dawning of a new era... \{ The hyenas start emerging) ...in which lion and hyena come together, in a great and glorious future."

(Nathanson, 2019: Scene, 30)

The quotation explains that Scar is the successor to the king in the Pride Lands after Mufasa's death and Simba's disappearance and he takes over the throne as the new King of the Pride Lands.

Another reason for Simba's seeking revenge is when his uncle slandered him that he killed his father during the events in the canyon. He forced Simba to admit his guilt in front of the lions and hyenas. After he forced Simba to admit it, Scar finally confessed this secret to Simba that it was he who actually killed his brother.

"Scar: $\{$ Delighted $\}$ Ahh, so you haven't told them your little secret.

Well, Simba, now's your chance to tell them. Tell them who is

responsible for Mufasa's death!

\{Scar's last line causes the lionesses to start. All are concentrating on

Simba. $\}$

Simba: $\{$ Steeling himself, then taking a step forward $\}$ I am.

\{Sarabi approaches her son.\}

Sarabi: $\{$ With much grief $\}$ It's not true. Tell me it's not true. 
Simba: $\{$ Regretfully $\}$ It's true.

Scar: You see! He admits it! Murderer! (Nathanson, 2019: Scene 18)

The above quotations show that the Mufasa manipulated the situation that Simba was the murderer of his father. Therefore, he remains the king of the Pride Lands.

\subsubsection{Goals of the Revenge \\ 4.1.2.1 Restoring Dignity}

The first goal of Simba's revenge is that Simba wants to return to the Pride Lands to take his rights as its king which had previously been taken over by his uncle. It is seen in the following quotation:

Simba: \{As Sarabi looks on with some pride\} Give me one good reason why I shouldn't rip you apart.

Scar: (Backing into a wall, apologetic) Oh, Simba, you must understand. The pressures of ruling a kingdom...

Simba: ...Are no longer yours. Step down, Scar.

Scar: Oh, oh, ye - Well, I would, heh, naturally, heh - however, there is one little problem. You see them? \{pointing to the horde of hyenas on the rocks above They think I'M king.

\{Nala appears with the rest of the lionesses. \}

Nala: Well, we don't. Simba is the rightful king.

Simba: The choice is yours, Scar. Either step down or fight.

Scar: Oh, must it all end in violence? I'd hate to be responsible for the death of a family member. Wouldn't you agree, Simba?

Simba: That's not gonna work, Scar. I've put it behind me."

(Nathanson, 2019: Scene, 55)

The quotations above show that the goal of Simba's revenge is because his uncle had taken the throne is supposed to be his. His uncle also thought that Simba had died during the events in the canyon earlier. Even though his uncle has taken the throne, Simba will take the throne from his uncle again.

The goal of Simba's revenge becomes the realty. Simba regains his rights as the king of the Pride Lands and lives in peace with Nala, the new queen of the kingdom and has a child. It can be seen in the quotation below:

"Rafiki: It is time.

\{Very majestically, he ascends through the rain. Music swells. Simba looks up through a hole in the clouds revealing the stars. One bright star shines out briefly.

Mufasa: Remember ...

\{Simba's expression gains confidence and strength. He roars. The lionesses roar in reply. Time switch to the savannah in full bloom again. Cue "Busa" theme:\}

BS: Busa le lizwe

\{Simba, Timon, Pumbaa, and Nala are on Pride Rock. Zazu flies up to the point. Timon, of course, is shaking his arms in the classic victory sign. All the groups of herds are there and making noise as in the presentation of Simba. 
\{Rafiki appears, holding a lion cub. He lifts the cub to present to show the crowd. Bass drum hit and black out to title in red lettering as in the beginning. The Circle is completed.\}"

(Nathanson, 2019: Scene, 60)

The above quotations show that Simba has finally become the king of the Pride Lands with his queen, Nala, and has a child. They live happily and peacefully since Scar's death there had been no intruders or obstacles for Simba to become king in the Pride Lands.

\subsubsection{Restoring the Honor}

The other second goal of the protagonist's revenge is after Scar's little secret was revealed they finally made an attack. It happened because Scar slandered Simba. He does not accept Scar's accusation that he is a murderer, even though he is the culprit. It is seen in the following quotations:

\{Nala starts towards Scar, the hyenas attack Simba in a wall of teeth.

The lionesses join in. We see Pumbaa and Timon come in. Pumbaa is charging with Timon riding him. Hyenas are flying everywhere.

Timon and Pumbaa: Heeeyyyy-yaaaaah!

Timon: 'Scuse me. Pardon me. Comin' through. Hot stuff. Whoo!

\{Bowling strike sound effect as hyenas fly. Rafiki whacks a hyena off

Simba. Camera switch to him; with a battle scream, he joins the fray.

As a bit of comic relief, Rafiki is fighting in kung-fu "B-movie" style, complete with cheesy sound effects. $\}$

Rafiki: \{As he hits various hyenas\} WwwA! Hozah! Hazoww! Yaa! Yah! hhyEEOOWww!

\{Camera switch to Timon running from Shenzi. He runs into the cave.

Zazu spots him. Timon runs into his cage for safety from the hyenas.\}

Pumbaa: Take that! And that! \{etc. \} You yellow belly..."

(Nathanson, 2019: Scene, 58)

The quotation shows that the goal of Simba's revenge by fighting back can make Scar and the hyenas realize that what he did was a mistake. The quotation also says that Simba is entitled to his right as successor to the throne.

\subsubsection{Teaching a Lesson to the Aggressor}

The third goal of Simba's revenge is to give a lesson to Scar. Simba chases Scar to the top of the Pride Rock. That is where Scar is cornered and he begs Simba not to kill him. Simba still has a conscience and he does not kill Scar. Simba only asks Scar to leave the Pride Lands and not come back like he did before to him. However, Scar has evil intentions towards Simba and tries to fight Simba again until he finally falls into a fiery abyss.

" $\{$ They start the Arsenio Hall "Ooh, ooh" chant. The scene switches to Simba chasing Scar up to the high point of Pride Rock. Scar runs up to the edge and sees the sheer drop. Simba leaps up to confront him at 
the cliff-like edge. Scar is very apprehensive, seeing he is cornered and at Simba's mercy.\}

Simba: \{Quietly, severely\} Murderer.

Scar: Simba, Simba. Please. Please have mercy. I beg you.

Scar: What are you going to do? You wouldn't kill your own Uncle...? \{Ingratiating grin\}

Simba: No, Scar. I'm not like you.

Scar: \{Greatly relieved\} Oh, Simba, thank you. You are truly noble. I'll make it up to you, I promise. How can I, ah, prove myself to you? Tell me; I mean, anything.

Simba: \{Gravely, with deep anger\} Run. Run away, Scar. And never return.

Scar: Yes. Of course. As you wish... \{Looking down and seeing a pile of hot coals\} ...your Majesty! \{Scar swipes the coals into Simba's face. With a cry of surprise and pain, Simba paws the coals away as Scar leaps and attacks.

\{There is a fight in slow motion. Both Scar and Simba land heavy blows. Simba gets knocked on his back. Scar leaps through the flames at him. Simba gathers courage and uses Scar's momentum in a "throw" similar to Nala's fighting tactics to send him flying over the edge. Scar tumbles to the bottom. He weakly gets up. He sees Banzai, Shenzi, and Ed approaching and smiles. Ed has a very angry look on his face.\} (Nathanson, 2019: Scene, 59)

The above quotation shows the goal of protagonist's revenge to Scar. Scar was thirsty for power so he willingly wanted to kill his nephew for the throne. Until the end he also got karma by falling into a fiery cliff and being eaten by his own troops, namely the hyenas.

\section{Conclusion}

After analyzing the film script thoroughly, it is true that the protagonist has revenge against an uncle. The search and purpose of revenge must be found in the script after the story in the script is well analyzed. From this analysis it can be concluded that revenge is also a form of hurt. Revenge is important for any injured victim, especially for the father. One child and father bond closer than the other. A child must defend his father, let alone be killed. From this analysis, several recommendations are put forwards as follows: Everyone should not take revenge because it will have a negative impact, Love your sibling's children as your own, give affection to your nephew according to his age, and always think positively about what happened.

\section{References}

Ary, Donald, Jacobs, L., C., Razavieh. (1985). Introduction to Research in Education. New York: Holt, Rinehart.

Ibrahim, Bafadal. (2011). Pengelolaan Perpustakaan Sekolah. Jakarta: Bumi Aksara.

Baron, Byrne \& Branscombe. (2005). Social Psychology. Boston: Pearson.

Cota-McKinley A. L, Woody W. D, \& amp; Bell, P. A. (2001). Vengeance: Effects of Gender, Age, and Religious Background. Aggressive Behavior. 
https://www.researchgate.net/publication/266677735_Gender_differences_in_tr ust_dynamics_Women_trust_more_than_men_following_a_trust_violation

Crombag, H., Rassin, E., \& amp; Horselenberg, R. (2003). On Vengeance. Psychology, Crime, and Law, 9. https://www.semanticscholar.org/paper/ON-VENGEANCECrombag-Rassin/500565b5ac7e4fc50bb168af8ae88c71f4155459

Eagleton, Terry. (2010). Teori Sastra: Sebuah Pengantar Komprehensif. Yogyakarta: Jalansutra.

Esten, Mursal. (1978). Kesusastraan Pengantar Teori \& Sejarah. Bandung: Angkasa.

Beaumont, Leland R. . (2009). EmotionalCompetency. https://www.amazon.com/Leland-R.Beaumont/e/BO0OAPZC3K\%3Fref=dbs_a_mng_rwt_scns_share

McCullough, M. E. (2008). Beyond Revenge The Evolution of The Forgiveness Instinc. San Fransisco: Jossey-Bass.

Minderop, Albertine. (2011). Psikologi Sastra: Karya Sastra, Metode, Teori, dan Contoh Kasus. Jakarta: Yayasan Pustaka Obor Indonesia.

Nathanson, Jeff. (2019). The Lion King. https://www.thecourieronline.co.uk/snowballs-2019-worst-screenplay-the-lionking-2019/

Ross, Michael, and Schumann, Karina. April (2010). The Benefits, Costs, and Paradox of Revenge. https://www.researchgate.net/publication/264324441_The_Benefits_Costs_and_ Paradox_of_Revenge

Sinclair, John. Eds. (1987). Collins Cobuild English Language Dictionary. London: William Collins Sons \& Ltd. 